\title{
Interpretacje
}

\section{Bruno Schulz: sztuka jako kulturowa ekstrawagancja}

Ryszard Nycz

TEKSTY DRUGIE 2016, NR 5, S. 182-197

DOI: $10.18318 /$ td.2016.5.13
Tekst przygotowany w ramach projektu Innowacyjna humanistyka polonistyczna: „tekst jako laboratorium" NCN nr UMO-2012/07/B/HS2/01451, wygłoszony na Schulzfestival w Drohobyczu w czerwcu 2016 roku.
1.

Bardzo dziękuję Wszystkim P.T. Organizatorom za zaproszenie, w szczególności Pani Wierze Meniok, legendarnej już spiritus movens festiwalu, której wielomiesięcznym zachętom i perswazjom nie umiałem się w końcu oprzeć. Powód tego dziwacznego mojego oporu jest prozaiczny, tzn. po prostu: merytoryczny.

Z jednej strony bowiem jestem świadom ogromnej i ciągle powiększającej się - biblioteki egzegez i wykładni dzieła Schulza, pióra najwybitniejszych polskich badaczy literatury oraz najwybitniejszych badaczy zagranicznych zajmujących się polską literaturą. Ten przytłaczający amatora nowej lektury kontekst sprawia, że każda próba dołożenia kolejnej cegiełki do schulzologicznego gmachu staje się zadaniem coraz bardziej ryzykownym, naznaczonym poważną groźbą niespełnienia, powtarzania czy marginalnego jedynie uzupełniania już powstałych odczytań.

Z drugiej strony zaś powodem mojego lekturowego oporu - którego dowodem choćby fakt, że nie pisałem dotąd osobno o tej twórczości - jest to, że mam problem
Ryszard Nycz - prof. dr hab., kierownik Katedry Antropologii Literatury i Badań Kulturowych U), pracownik IBL PAN. Redaktor naczelny „Tekstów Drugich". Członek korespondent PAN I PAU, KNoL PAN i KNoK PAN. Przewodniczący Komitetu Redakcyjnego serii "Nowa Humanistyka". Ostatnio opublikował: Poetyka doświadczenia. Teoria - nowoczesność - literatura (2012). Kontakt: ryszard. nycz@uj.edu.pl. 
z Schulzem. Mam problem z jego dziwaczną „retoryką przesady”, ocierającą się nierzadko o pompatyczną pretensjonalność, której nie jest w stanie rozbroić ostatecznie nawet najgłębiej sięgająca Schulzowska ironia. Mam problem z rozszyfrowaniem tzw. głębszego sensu dziwacznej ludzkiej menażerii tego świata, natury jej dążeń i celu jej aktywności. Mam problem z uchwyceniem antropologicznej racji bytu tego osobliwego, bardzo idiomatycznego, choć zarazem bardzo wiele czerpiącego z kulturowej pamięci, egzystencjalno-artystycznego projektu, dla którego kategoria „osobistej mitologii" (podsuwana przez autora) wydaje się raczej maskującą licencją poetycką niż wyjaśnieniem (zasługuje więc przynajmniej na nowe odczytanie), i w którym padające deklaracje estetyczno-światopoglądowe trudno brać prostodusznie za dobrą monetę, ponieważ jaskrawo przeczy im pisarska praktyka. Mam wreszcie problem - bardzo podstawowy, elementarny z dziwną semantyczną organizacją tych utworów, które skutecznie wymykają się hermeneutycznym procedurom przekonującej egzegezy, pozostając jak gdyby trwale (strukturalnie?) otwarte; oczekujące dopełnienia przez sens, który pozostaje nieziszczalną obietnicą...

Oczywiście są to moje problemy, których nikt nie musi podzielać. To zbyt długie wyznanie strapionego czytelnika dzieła Schulza wydało mi się jednak niezbędne, by określić punkt wyjścia proponowanej lektury oraz własny punkt widzenia; świadomość wejścia niejako w rolę Schulzowskiego bohatera jako „zawstydzonego zuchwalca” na elitarnej scenie schulzologii czy stremowanego uzurpatora, roszczącego sobie prawo do posiadania wiedzy o zagadce tej twórczości. Mam nadzieję, że choć w części usprawiedliwia mnie fakt, że próbuję tu sobie coś wytłumaczyć.

Jako osoba dostatecznie przyuczona do zawodu zakładam, że to nie przypadek, że te „dziwności” i „dziwaczności” są znaczące i nie powinny być pomijane w próbach np. silnej interpretacji, profilującej odczytanie w nowej, odkrywczej, jednorodnej perspektywie. Co więcej, doszedłem do przekonania, że klucz do tej zagadki nie jest zaszyfrowanym kodem ukrytych znaczeń, lecz leży na widoku (niczym skradziony list w opowiadaniu E.A. Poego) i jest nim właśnie wieloznaczna, wielowymiarowa, spotęgowana dziwaczność dzieła Schulza..., czyli tytułowa ekstrawagancja. W poniższych czterech częściach, dotyczących czterech wspomnianych problemów z rozumieniem Schulzowskich „dziwności”, postaram się naszkicować jej topografię, choć, z konieczności, ograniczając się do literatury (jakkolwiek sądzę, że dałaby się zastosować także do jego prac plastycznych) i tylko sygnalizując jej strategiczne tropy analityczne. 
Zanim jednak do nich przejdę, podam niezbędne słownikowe wyjaśnienia. „Ekstrawagancja” w słowniku Schulza występuje bodaj raz, w opowiadaniu Ptaki: „Nie rozumieliśmy wówczas jeszcze smutnego tła tych ekstrawagancyj, opłakanego kompleksu, który dojrzewał w głębi" (P, 67) ${ }^{1}$. Jednak jej ekwiwalencje, które są wyliczane przez słowniki owoczesne, należą już do najczęściej wykorzystywanych określeń w tej prozie. Słownik warszawski: ekstrawagancja - dziwaczność, dziwactwo, niedorzeczność; ekstrawagować - pleść niestworzone rzeczy, opowiadać banialuki; ekstrawagant (praw.) - dopełnienie zasadniczych postanowień statutu [ten trop może prowadzić do „regionów wielkiej herezji”, czym nie będę się tu zajmował]. Słownik Arcta: zachować się przesadnie, dziwactwo, nadużycie, wybryk. Encyklopedia Gutenberga: wybujały, przesadny, dziwaczny. Do tego dochodzą ważne znaczenia etymologiczne: extra + vagari - wędrować poza, na zewnątrz; extra vagans - schodzący na manowce, błąkający się, błądzący; oraz extravagans (średniowieczne, prawnicze) - promulgowalny (czyli ogłaszany) poza prawem kanonicznym.

\section{2.}

Ekstrawagancje stylistyczno-retoryczne prozy Schulza zwracały polemiczną uwagę już pierwszych jej krytyków (Wyki, Napierskiego); niewątpliwie są od razu rozpoznawalną wizytówką jego idiomu pisarskiego. Oto parę przykładów na chybił trafił: „nigdy niezgłębiona istota ognia” (P 66), „matka pełna troski i zmartwienia” (P 67), „leżąc twarzami na futrzanym brzuchu ciemności, odpływaliśmy na jego falistym oddechu w bezgwiezdną nicość" (P 74), ,amalgamat świtu przekwital” (P 74), , bezimienna twarz nocy” (P 76), „nieobjętość transcendentu” (P 161), „dyferencjalna analiza nocy toczyła się z siebie samej" (P 307)..., a więc skłonność do pleonastycznego rozmnażania bliskoznacznych określeń i maksymalizacji natężenia cech, do substancjalizacji i uzmysłowienia abstraktów, specjalistycznych terminów technicznych czy naukowych, do patetycznego zwielokrotniania określeń niewyrażalnego - wszystko to dobrze widoczne w autoironicznym samookreśleniu: „patos przymiotników i napuszystość epitetów wobec tej rzeczy bez miary, wobec tej świetności bez rachuby" (P 161). Nie ma wątpliwości, że ta retoryka przesady stanowi równie niewątpliwe wyzwanie lekturowe dla czytelnika (w tym i dla mnie).

1 Tak oznaczam w tekście cytaty z B. Schulz Proza, przedm. A. Sandauer, oprac. listów J. Ficowski, Wydawnictwo Literackie, Kraków 1964. 
Na pierwszy trop rozumienia ekstrawagancji stylistycznej maniery naprowadził mnie dawno temu Henry David Thoreau, ale dopiero lektura pracy Roberta Bakera pozwoliła na jego rozwinięcie. Thoreau, w konkluzjach swych patetycznych medytacji w Waldenie, pisze tak:

Ponad wszystko obawiam się głównie tego, że mój sposób wyrażania się nie będzie dostatecznie ekstrawagancki, że niedostatecznie wykroczy poza wąskie ramy mojego codziennego doświadczenia, aby odpowiadać prawdzie, o której jestem przekonany. Ekstrawagancja! Cóż, zależy od tego, do jakiej zagrody człowieka wpędzono. Wędrujący bawół, który szuka nowych pastwisk na innej szerokości geograficznej, nie jest tak ekstrawagancki jak krowa, która kopniakiem przewraca wiadro, przeskakuje płot i biegnie za cielakiem w porze dojenia. Chciałbym móc się gdzieś wypowiedzieć bez ograniczeń, jak budzący się człowiek, który przemawia do budzących się ludzi, albowiem jestem przekonany, że nie mogę przesadzić nawet do tego stopnia, ażeby położyć fundamenty prawdziwej wypowiedzi. Kto spośród tych, którzy słyszeli kiedyś tony muzyki, obawiał się, że może sam przemawiać przesadnie? Z myślą o przyszłości lub prawdopodobnych wydarzeniach powinniśmy wieść życie na zewnątrz swobodne i bez ograniczeń, niewyraźnie i mgliście po tej stronie zarysowane; tymczasem nasze cienie spływając niedostrzegalnym potem, wyciągają się ku słońcu. Ulotna prawda naszych słów powinna bezustannie zdradzać niewłaściwość reszty wypowiedzi. Prawdę słów natychmiast się tłumaczy, to, co pozostaje, jest tylko sztancą jej dosłowności. Słowa, które wyrażają naszą wiarę i pietyzm, są niekonkretne, a jednak dla natur wyższej miary istotne i wonne jak kadzidło. ${ }^{2}$

Dla Thoreau, podobnie jak dla Schulza, ekstrawagancje stylu byłyby więc sposobem nie tyle przełamywania ograniczeń (bo to niemożliwe) standardowej komunikacji językowej, ile identyfikacji owych językowych barier blokujących swobodę wyrazu prawdy ludzkiego doświadczania rzeczywistości, która zatem dzięki temu właśnie zabiegowi (sztuczności, nienaturalności) może dochodzić do głosu, jakkolwiek wyłącznie via negativa: „zdradzając niewłaściwość reszty wypowiedzi". Nie bardzo zgadza się to z deklaracjami pisarza, ale tylko wtedy, gdy rozumieć je nazbyt prostodusznie. „Nienazwane

2 H.D. Thoreau Walden czyli życie w lesie, przeł., przedm. i przyp. H. Cieplińska, PIW, Warszawa 1991, s. 381-382. 
nie istnieje dla nas" (P 443) - to sławne dictum Schulza nie oznacza, jak można by sądzić i jak rozumiał je młody Wittgenstein, że "granice mego języka są granicami mego świata”, ale raczej, jak rozumiał je Wittgenstein „stary”, uzasadnienie potrzeby szukania dostępu do tego, co w języku wyrazić się nie może; u Schulza zaś przede wszystkim tego, co wzniosłe, niewyrażalne („kuszą mnie... coraz bardziej niewyrażalne tematy", KL 179³). Jak pisał Schulz swym precyzyjnie ekstrawaganckim stylem, „żadne słowo, żadna aluzja nie potrafi zalśnić, zapachnieć, spłynąć tym dreszczem przestrachu, przeczuciem tej rzeczy bez nazwy, której sam pierwszy posmak na końcu języka przekracza pojemność naszego zachwytu" (P 161).

Otóż taki jest właśnie (według mnie) pogląd pisarza: dostęp do realności uzyskujemy tylko w formie „posmaku [tej rzeczy bez nazwy - R.N.] na końcu języka”. Kiedy, szukając brakującego, właściwego słowa, wydaje się nam, że mamy je „na końcu języka”, to choćbyśmy go nie znaleźli, pozostaje ono rzeczywistym acz niewyrażonym słowem - o czym świadczy np. odrzucanie innych określeń jako „niewłaściwych”. Podobnie z prawdziwą rzeczą i rzeczywistością: jest nam dostępna tylko „na końcu języka”, przez niekończące się próby jej wyrażania i nazywania „niewłaściwym”, sztucznym językiem, który nigdy nie stanie się „językiem rzeczy”, ale który daje nam pozawerbalny i pozapojęciowy, zmysłowo-afektywny "posmak” nawiązanego z nią kontaktu.

Robert Baker w The Extravagant. Crossings of Modern Poetry and Modern Philosophy czerpie inspiracje z cytowanego wyżej fragmentu Waldena Thoreau, argumentując, że pojęcie „ekstrawagancji” może stać się bardziej operacyjną kategorią analizy przemian poezji nowoczesnej (od romantyzmu do współczesności), a także ewolucji myśli filozoficznej (od Hegla do Derridy i Nancy’ego) niż kategoria wzniosłości, która dotąd w tym celu bywała szeroko wykorzystywana. W jego ujęciu filozoficznie przepracowana kategoria ekstrawagancji (aktywująca znaczenia wymienione przeze mnie na początku) pozwala objąć trzy kluczowe drogi artystyczno-filozoficznego rozwoju szeroko rozumianej nowoczesności. Po pierwsze, doświadczenie wzniosłości, objawiające swą kreatywną sprawczość zwłaszcza w języku innowacyjnych dzieł sztuki (modernistycznych i awangardowych), za sprawą której rozkładają one i przekraczają normatywne ramy i ograniczenia kontekstów, w których się pojawiają. Po drugie, faustyczne poszukiwania, w których „twórcze

3 Tak oznaczam w tekście cytaty z B. Schulz Księga listów, wyb., oprac., wstęp, przyp. i aneks J. Ficowski, Wydawnictwo Literackie, Kraków 1975. 
destrukcje i destrukcyjne kreacje" prowadzą do transformacji oraz rozszerzenia granic naszego doświadczenia. Po trzecie, doświadczenie bezdennej, bezpodstawnej negatywności, która warunkuje, porusza i przełamuje nasze schematy pozytywnej wiedzy oraz jasnej i wyraźnej reprezentacji ${ }^{4}$. Wydaje się, że nie ulega wątpliwości, iż twórczość Brunona Schulza nie tylko może być - ale już niejednokrotnie bywała - rozpatrywana w tych trzech istotnych perspektywach analitycznych ${ }^{5}$, co pozwala tu poprzestać na zasygnalizowaniu jedynie tych możliwości.

$\mathrm{Z}$ cytowanego fragmentu Waldena Baker wyprowadza m.in. jeszcze jedną, ogólniejszą refleksję, która i dla twórczości Schulza ma niebłahe znaczenie. Komentując Thoreau „ekstrawaganckie” pragnienie podróży poza konwencjonalne egzystencjalne i językowe granice, pyta, czy chodzi tu raczej o wędrówkę przede wszystkim egzystencjalną, która może być jedynie adekwatnie przekazana przez lingwistyczne „błądzenia”, czy też przeciwnie; ta ekstrawagancka wędrówka ma zasadniczo charakter wędrówki językowej (odchodzenia od norm prostoty i komunikatywności), która prowadzi do eksperymentalnej podróży egzystencjalnej; czy wreszcie chodzi o jedno i drugie, a rodzaj sprzężenia zwrotnego między tymi „wędrówkami” określa właśnie ambiwalencję bardzo charakterystyczną dla tak zdefiniowanego pisarstwa „ekstrawaganckiego"6. Wydaje się, że tak też jest i u Schulza. Z jednej strony język, styl jego pisarstwa generuje stany rzeczy, fabularne przygody i przemiany, buduje nastrój tematyczny, kierunek poszukiwań egzystencjalnych. Z drugiej - egzystencjalny projekt Schulza nie mógł znaleźć lepszej

4 Streszczam tu i parafrazuję syntetyczną autocharakterystykę argumentacji R. Bakera w jego The Extravagant. Crossings of Modern Poetry and Modern Philosophy, University of Notre Dame, Notre Dame 2005, s. 269-270.

5 Spośród prac poświęconych interpretacji prozy Schulza w tych trzech nurtach zob. m.in.: A. Bielik-Robson Życie na marginesach. Drobny aneks do kwestii „Bruno Schulz a kabała chasydzka", w: Schulz. Przewodnik Krytyki Politycznej, Wydawnictwo Krytyki Politycznej, Warszawa 2012; W. Bolecki Poetycki model prozy w dwudziestoleciu międzywojennym: Witkacy, Gombrowicz, Schulz i inni: studium z poetyki historycznej, Universitas, Kraków 1996; D. Głowacka Wzniosła tandeta i „simulacrum". Bruno Schulz w postmodernistycznych zaułkach, "Teksty Drugie" 1996 nr 2/3; J. Jarzębski Prowincja Centrum. Przypisy do Schulza, Wydawnictwo Literackie, Kraków 2005; M.P. Markowski Powszechna rozwiq̨złość. Schulz, egzystencja, literatura, Wydawnictwo UJ, Kraków 2012; W. Panas Księga blasku. Traktat o kabale w prozie Brunona Schulza, TNKUL, Lublin 1997; K. Stala Na marginesach rzeczywistości. O paradoksach przedstawiania w twórczości Brunona Schulza, Wydawnictwo IBL PAN, Warszawa 1995; Słownik Schulzowski, red. W. Bolecki, J. Jarzębski, S. Rosiek, słowo/obraz terytoria, Gdańsk 2003.

6 R. Baker The Extravagant..., s. 4. 
artykulacji niż w tym przesadnym i przekraczającym konwencjonalne normy dyskursie. Z trzeciej zaś - ta właśnie ambiwalencja, wzajemne podtrzymywanie i podważanie się obu wymiarów decyduje o autentyczności i osobliwości idiomu twórczego projektu - życiowego i artystycznego - Schulza.

\section{3.}

Najlepsze rozwiązanie problemu ekstrawagancji wyglądu i zachowania postaci świata przedstawionego prozy Schulza podsunął nieomal od razu Witold Gombrowicz, w niedużej recenzji z Sanatorium pod Klepsydrą (gdzie nota bene określenia: dziwna, dziwak, dziwaczna - pojawiają się kilkakrotnie). Zastanawiając się nad wewnętrzną logiką intrygi tytułowego opowiadania zbioru, przyznaje, że rozważana w kategoriach prawdopodobieństwa i zdrowego rozsądku, jest to „kupa absurdów” („Bohater odwiedza ojca, który żyje «rozluźnionym» życiem na bliżej nie określonej zasadzie «cofniętego czasu» w półsennym miasteczku; odbywszy drzemkę z ojcem bohater wałęsa się po rynku, zachodzi do sklepu, w którym niespodziewanie otrzymuje przesyłkę: mały składany teleskop. Bohater nasz rozkłada teleskop, który delikatnie przeobraża się w samochód i uwozi go na rynek. Po czym w miasteczku wybucha wojna i rewolucja. Bohater wraca do pensjonatu, ale tutaj wyskakuje na niego pies - jednakże okazuje się, że to nie pies, lecz człowiek, a właściwie człowiek przełamujący się w psa i pies w człowieka. Bohater ucieka"'.

W tej dobrze znanej, zasłużenie klasycznej wykładni Schulzowskiego uniwersum najważniejsze wydają się wnioski wyciągnięte z naszkicowanej analizy: „Schulz wybiera - powiada Gombrowicz - zupełnie dowolne i przypadkowe elementy, buduje z nich świat odrębny - my zaś na tym sztucznym i fikcyjnym świecie możemy śledzić te same siły i te same prawa, które panują na świecie realnym, z tym jednak, że występują one bez porównania wyraźniej i silniej, gdyż przypadkowość i fikcyjność ich formy (a więc np. postaci i zdarzeń, w jakich się objawiają) zostaje zdekonspirowana"8. W myśl tej koncepcji, która zresztą słusznie może uchodzić i za autodefinicję pisarstwa samego Gombrowicza, byłoby nieporozumieniem doszukiwać się w dziele Schulza "logicznego wątku fabularnego" czy „konkretnej psychologii postaci”,

7 W. Gombrowicz Twórczość Brunona Schulza, w tegoż Proza (fragmenty), reportaże, krytyka 1933-1939, Dzieła tom 12 Varia, Wydawnictwo Literackie, Kraków 1995, s. 365.

8 Tamże, s. 367. 
a w ogólności, dopowiem, urzeczywistniania jakichkolwiek zasad fikcjonalnej reprezentacji. Można by powiedzieć raczej, że Schulz buduje artystyczne laboratorium, w którym na pozór „zupełnie dowolne i przypadkowe elementy" (na pozór, bowiem z tym określeniem Gombrowicza trudno się zgodzić; z reguły chodzi o zaskakujące przenikanie się nieprzypadkowo wybranych elementów demaskatorsko realistycznych z fantazmatycznymi) zestawione są w celowo „ekstrawagancki” sposób, dzięki któremu naruszana konwencja, przekraczana norma, złamana reguła - zostają stematyzowane, uobecnione oraz poddane subwersywnej krytyce.

Gombrowicz parokrotnie odnotowuje istotną rolę, jaką odgrywają w tym procesie emocje („powaga odczucia każdej z osobna emocji”; „nie chodzi tutaj o psa, tylko o samą emocję strachu [...], samą jego «jakość wewnętrzną», która pozostaje ta sama pod maską zmienionego kształtu"9); emocje, których aranżacja w nastrojową jedność, ton, czy atmosferę (sam Schulz pisał o „klimacie") zapewnia opowiadaniom koherencję oraz afektywno-semantyczną dynamikę. I choć nie przekłada się ona na efekt pojęciowej reprezentacji pozajęzykowej rzeczywistości, to działanie (i oddziaływanie) dyskursu Schulzowskiego pozostaje wysoce skuteczne, sprawcze, angażujące wyobraźnię i doświadczenie czytelników. Zdaniem Hansa-Ulricha Gumbrechta dzieje się tak dlatego, że to, „co porusza nas przy czytaniu, jest częścią substancjalnej prezencji minionych przeszłości - a nie znakiem przeszłości albo jej reprezentacją. [...] «Czytanie nastrojów» nie może oznaczać «rozszyfrowywania nastrojów», bo nastroje to nie znaczenia. [...] «Czytanie nastrojów» to odkrywanie nastrojów w tekstach i innych artefaktach, afektywne i także fizyczne wchodzenie z nimi w bliski kontakt i wskazywanie na nie. [...] A dopóki nastroje docierają do nas fizycznie i afektywnie, rzeczą zbędną jest także chęć dowodzenia, że nasze języki potrafią dosięgnąć rzeczywistości poza nimi samymi. Sceptycyzm «konstruktywizmu» czy linguistic turn dotyczy bowiem tylko tych ontologii literatury, które opierają się na paradygmacie reprezentacji świata. Czytania nastrojów to nie dotyczy - one należą do rzeczywistości świata"10.

W moim przekonaniu uwagi Gumbrechta można bez zmiany odnieść do prozy Schulza, bowiem jego tak charakterystyczna, uderzająca cecha stylu,

Tamże, s. 366,367 .

10 H.-U. Gumbrecht Czytanie nastrojów. Jak można pomyśleć dziś rzeczywistość literatury?, przeł. A. Żychliński, w: Teoria, literatura, życie. Praktykowanie teorii w humanistyce współczesnej, red. A. Legeżyńska, R. Nycz, Wydawnictwo IBL PAN, Warszawa 2012, s. 165-171. 
jaką jest „przeżyciowa”, afektywno-zmysłowa „prezencja” obiektów i zdarzeń w środowisku „kulturonatury"11, wytwarza w rezultacie właśnie efekt partycypacji w - a nie reprezentacji - doświadczanej rzeczywistości.

By dać przykład lekturowej mikroanalizy tego rodzaju techniki, posłużę się sugestywnym jednozdaniowym opisem obrazu pogrążonego w „nocy, szumiącej jak muszla” miasteczka - obrazu, który prawie kompulsywnie do mnie powraca: „W świetle błyskawicy ujrzałem ojca mego w rozwianej bieliźnie, jak ze straszliwym przekleństwem wylewał potężnym chlustem w okno zawartość nocnika w noc, szumiącą jak muszla" (P 62). Myślę, że jest to prawdziwy okaz skażonego piękna „schulzyzmu” w pigułce. W emfatyczno-nadekspresywnym opisie ojciec, ujrzany w sekundowym rozbłysku, zostaje uwieczniony w geście, w którym uwalnia się od nieczystości duszy (straszliwe przekleństwo) i ciała (zawartość nocnika) - ekspulsując je w kosmiczne zewnętrze nocy, która dostraja się do tej napiętej atmosfery przyrodniczą ekspulsją (błyskawice), by tymi wszystkimi odgłosami poetycko „szumieć, jak muszla”. A ten groteskowy splot wzniosłości i obsceniczności, ekscytacji i wstrętu pozwala nam zarazem wyciągnąć wnioski o bardziej „realistycznym” charakterze (np. o stanie sanitarno-kanalizacyjnym miasta, o rytuałach fizjologicznych jego mieszkańców, o ich skłonnościach do nadpobudliwości emocjonalno-duchowej), jak i dostarczyć pożywki do rozwoju fantazmatycznych wyobrażeń.

Wystarczy bowiem w geście ojca dojrzeć przykład podobnych praktyk innych ojców rodzin, by móc odczuć i usłyszeć, jak chóralne pogłosy ich dziwacznie-wzniosłych, wysublimowanych tyrad mieszają się z rytmicznymi odgłosami „straszliwych przekleństw” oraz „potężnych chlustów” spływających ulicami nieczystości - łącząc się ostatecznie w bukiet zapachów, dźwięków i płynów, unoszący się nad miastem strumieniem przyciągająco-odpychających, fascynująco-obrzydliwych, duchowo-fizjologicznych wrażeń, który tworzy ów niepowtarzalny klimat, zmysłowo-afektywny nastrój, a także specyfikuje nienazwane ingrediencje „nocy, szumiącej jak muszla” prowincjonalnego miasteczka...

11 Wprowadzając tę kategorię, chciałbym zasugerować wartą osobnej analizy strategię artystyczno-antropologiczną Schulza, polegającą na sprzężeniu zwrotnym, przechodzeniu w siebie nawzajem obu kategorii, a nawet zakwestionowaniu opozycji (kultury i natury) między nimi, widoczną np. w opisach, w których miasto jest metaforyzowane w kategoriach przyrodniczych, a opisy natury - w kategoriach cywilizacyjno-technologicznych, a także w modelowaniu opisów postaci ludzkich w kategoriach zwierzęcych oraz, oczywiście, w metamorfozach Ojca itp. itd. 
Tak, właśnie w ten sposób (jak rozumiem), na realistyczno-fantazmatycznym i wzniośle-satyrycznym sugestywnym obrazie „zaszczepiają się" stany afektywne, które następnie stają się „widmowymi” mediami w sprawczym sensie, a więc czynnymi nosicielami znaczeń, jakie musi przyswoić i rozwinąć czytelnik Schulzowskich opowiadań.

\section{4 .}

Mam wrażenie, że antropologiczno-kulturowy kontekst artystycznego projektu Schulza pozostaje dotąd niedopowiedziany - choć jest całkiem wyraźny: to dyfuzjonizm. W czasach Schulza orientacja ta była najsilniej reprezentowana przez szkołę austriacko-niemiecką, angielską i amerykańską, ale dziś jej pogłosy także są wyraźnie słyszalne, i to nie tylko w badaniach stricte antropologicznych, ale również np. w studiach postkolonialnych, teorii systemu światowego i teorii zależności czy w studiach nad literaturą światową. Warto też zauważyć, że w literaturoznawstwie swoistym odpowiednikiem dyfuzjonizmu były badania nad wpływami i zależnościami, potem kontynuowane w ramach poetyki intertekstualnej, a dziś uprawiane w ramach studiów nad pamięcią kulturową.

Ten antropologiczno-kulturowy kontekst istotny jest nie tylko dlatego, że w prozie Schulza, jak wiadomo, „wszystko dyfunduje poza swoje granice” (P 682)..., aczkolwiek użycie tego określenia przez pisarza z pewnością nie było przypadkowe. Powodów jest więcej. Rozważmy kilka kluczowych tez dyfuzjonistów i Schulza - które pozwolą zaobserwować te powinowactwa ${ }^{12}$. Po pierwsze, kultura nie jest zintegrowanym systemem (ani autonomiczną strukturą) - to zbiór elementów (Schulz mówi o „inwentarzu”), które w danym obszarze kulturowym splatają się w specyficzny węzeł (uchodzący czasem za figurę tożsamościową), a następnie rozplatają się i wchodzą w kolejne konfiguracje. Richard Lowie, jeden z najwybitniejszych reprezentantów tego ruchu, jest autorem głośnego określenia kultury jako „bezładnej mieszaniny strzępów i łat"13, pożyczonych czy przejętych z innych kręgów kulturowych.

12 Zob. w tej sprawie m.in.: A. Kuper Kultura. Model antropologiczny, przeł. I. Kołbon, Wydawnictwo UJ, Kraków 2005; E. Nowicka Dyfuzja kulturowa, w: Encyklopedia socjologii, tom 1, Oficyna Naukowa, Warszawa 1998; R. Linton Dyfuzja, w: Elementy teorii socjologicznych, PWN, Warszawa 1975; A. Waligórski Antropologiczna koncepcja człowieka, PWN, Warszawa 1973. 
Według Schulza, przypomnijmy raz jeszcze, „wszystko dyfunduje poza swoje granice, trwa tylko na chwilę w pewnym kształcie, ażeby go przy pierwszej sposobności opuścić" (P 682), jak dzieje się z postacią ojca, po której pozostało "trochę cielesnej powłoki” oraz "garść bezsensownych dziwactw” (P 65). Chodzi bowiem o to, po drugie, że o rozwoju kultury nie przesądzają wcale wynalazki, lecz przede wszystkim zapożyczenia, przenikanie, reprodukowanie wzorów i wytworów kultury oraz intensywność kontaktów międzykulturowych. Dyfuzjonistycznej migracji wzorów odpowiada Schulzowska „wędrówka form”, która „jest istotą życia” (P 682). Zdaniem niektórych dyfuzjonistów, po trzecie, źródło wszelkiej różnorodności - jak też jedności - kultur mogło być jedno (kolebką kultury miał być starożytny Egipt), z którego miały wywodzić się wszelkie inwarianty kulturowe rozpowszechnione na całym świecie. Bardzo to pokrewne spekulacjom Schulza o mateczniku, jądrze, korzeniach kulturowych rzeczy... Kultura jest zasadniczo pojmowana w tym nurcie (a też i przez Schulza), po czwarte, jako zastany zespół norm kontrolujących ludzkie działania, repertuar scenariuszy zachowaniowych, które wyznaczają z reguły nieprzekraczalne - w praktyce - granice ludzkiej swobodnej aktywności. Z tej perspektywy widziana kreatywność, inwencja, wynalazczość są albo przejawami „twórczości przetwórczej” (jak to nazywał Karol Irzykowski), albo wyjątkami, ostatecznością, niewytłumaczalnymi ekscesami. Dzieje się tak dlatego, po piąte, że człowiek - wedle dyfuzjonistów i Schulza - jest istotą zasadniczo inercyjną, skłonną raczej do rutynowej reprodukcji postaw i ról, niźli do ich „ekstrawaganckiego" przekraczania, eksperymentów i poszukiwań.

Sygnalizuję te powinowactwa nie po to, by robić z Schulza antropologa (choć w fantazmatycznych a nierzadko dotkliwie uważnych opisach twarzy, postaw, zachowań daje się odczuć etnologiczna żyłka badacza „ludzkiego zwierzyńca” - określenie Sloterdijka), lecz by zauważyć, że Schulz w prowincjonalnym, zatopionym w inercji i marazmie, sennym miasteczku, tym mateczniku własnej egzystencji i wyobraźni, odkrywa modelową, prototypową postać ludzkiego świata. Jest to świat, w którym zachowania ludzi poddane są dwóm odwiecznym i zarazem bardzo nowoczesnym pasywnym afektom: nudzie i oczekiwaniu ${ }^{14}$. Świat, w którym nowość (znamiona czy atrybucje

w pracy The History of Ethnological Theory (Farrar and Rinehart, New York 1937) - zob. A. Barnard Antropologia. Zarys teorii i historii, przeł. S. Szymański, wstęp ). Tokarska-Bakir, PIW, Warszawa 2016, s. 102. 
nowoczesności) jest dyfuzyjnym zapożyczeniem, reprodukcją wzoru życia z centrum kulturowego. Świat, w którym ludzka kreatywność nawet w codziennych działaniach, a już zwłaszcza twórczość, sztuka, literatura jest kulturową ekstrawagancją i extra-wagancją: wędrówką poza granice i normy kulturowo usankcjonowanych scenariuszy ludzkiej aktywności i standardów zachowaniowych.

5.

Metoda twórcza Schulza oraz skorelowana z nią strategia czytania nie cieszyły się dotąd szerszą osobną uwagą ${ }^{15}$, a bezsprzecznie są tego warte. Przy czym trzeba od razu przyznać, że uwagi pisarza na temat procesu twórczego są paradoksalne. Paradoks polega na tym, że Schulz uroczyście proklamuje obowiązywanie esencjalistycznych ujęć rozpatrywania zjawisk (w tym procesu twórczego oraz tekstu i jego znaczenia), a równocześnie charakteryzuje je bliżej za pomocą metafor i opisów, które albo grają na homonimiach przeciwstawnych znaczeń (transcendencja jako byt absolutny i jako proces wykraczania poza, substancja jako fundament i jako „stan płynny”), albo „rozpuszczają” owe esencje w procesie rozwoju, przygodności relacji ze środowiskiem i otwartości na dopełnienie czy zmiany. Tak właśnie dzieje się w przypadku wyznań o genealogii i genezie własnej twórczości.

W liście do S.I. Witkiewicza czytamy o arche-obrazach z dzieciństwa, które są źródłem i programem całej późniejszej twórczości; „statuują żelazny kapitał ducha", a "cała reszta życia upływa nam na tym, by zinterpretować te wglądy”, twórczość takich artystów „jest dedukcją z gotowych założeń”, „nieustanną egzegezą, komentarzem do tego jednego wersetu, który im był zadany" (P 681). Arche-obrazy te zawierają więc w sobie gotowy depozyt niewyczerpywalnych znaczeń symbolicznych. Z drugiej wszakże strony nie mają one w sobie niczego pojęciowo czy językowo określonego, są bowiem

Essays on Boredom and Modernity, ed. B. Dalle Penze, G. Sahani, Editions Rodopi, Amsterdam 2009; E. Goodstein Experience Without Qualities: Boredom and Modernity, Stanford University Press, Stanford 2005. W sprawie drugiej: por. m.in. uwagi na temat "mesjanizmu bez Mesjasza” w dalszej części szkicu.

Zob. jednak w tej kwestii dwie niedawne prace analizujące Odpowiedź na ankietę „Wiadomości Literackich" - kluczowy tekst B. Schulza w tej mierze: M.P. Markowskiego Powszechna rozwiqzłość... oraz A. Daukszy Poetyka afektywna Brunona Schulza. Rekonesans, w: Historie afektywne i polityki pamięci, red. E. Wichrowska, A. Szczepan-Wojnarska, R. Sendyka, R. Nycz, Wydawnictwo IBL PAN, Warszawa 2015 (rozpatrujący poetykę Schulza w kategoriach afektywnych). 
dane „w formie przeczuć i na wpół świadomych doznań” (P 681), ich sekret do końca "pozostaje [...] nierozwikłany” (P 681), a co więcej, "grają rolę tych nitek w roztworze, dookoła których krystalizuje się dla nas sens świata” (P 680). Koncepcja „krystalizacji” znaczenia zaś jest przeciwieństwem koncepcji znaczeniowego „kapitału”; to, co w tej drugiej jest językowo-pojęciowym wykładaniem (i wyjaśnianiem), wyprowadzaniem na zewnątrz i na powierzchnię tego, co już wcześniej zostało zdeponowane we wnętrzu - w tej pierwszej jest procesem stopniowego osadzania się znaczenia w rezultacie rozwijania, nawarstwiania i zacieśniania się sieci doświadczanych związków. Wedle tej drugiej znaczenie jest dane wcześniej, ale zaszyfrowane, wedle pierwszej - jest dopiero zadane (czy też uznawane, zawsze ex post, za antycypację zdarzenia późniejszego), a budowane przez powierzchniowo zawiązywane konstelacje kojarzonych elementów. Nie jest łatwo pogodzić (czy bodaj skorelować) te stanowiska, a różnica między nimi jest istotna i bogata w konsekwencje. Być może w jakieś mierze zdają z niej sprawę uaktywnione tu homonimiczne znaczenia wieloznaczności: jako polisemii (kumulatywnej profuzji znaczeń) oraz dyseminacji (dyfuzyjnego rozsiewania znaczeń w kontekstowych sieciach).

To w stronę dyseminacji skłania się właśnie koncepcja „krystalizacji”, która zdominowała ostatnią, najważniejszą (choć też bardzo krótką) wypowiedź Schulza o własnym procesie twórczym w Odpowiedzi na ankietę „Wiadomości Literackich" z kwietnia 1939 roku (KL 179). Wyznanie to warte jest skrupulatnej analizy, na którą nie ma tu miejsca. By uzmysłowić odrębność stanowiska Schulza, warto zestawić je z innym metaforycznym modelem procesu twórczego, za którym np. opowiadała się jego artystyczna promotorka, Zofia Nałkowska. Konsekwentnie obstawała za preformacją (uprzednim ustaleniem) zawartości treściowej, której tekst był (tylko?) realizacją, wypowiedzeniem. Do legendy już przeszła jej „inżynierska” technika pracy, polegająca na rozplanowaniu na tablicy przebiegów fabularnych powieści, a następnie obmyślaniu i zapisywaniu pojedynczych zdań, które przypinała szpilkami krawieckimi w z góry zaplanowanych miejscach tekstowej struktury.

Całkiem inaczej wygląda to u Schulza. We wspomnianym tekście pisze on o planowanych (powstających?) czterech opowiadaniach, że ich temat jest „nieważny i trudny do zreferowania”; czyli, że nie wiadomo - i że jest nieistotne - o czym one są (bo też „nie wiadomo właściwie, co nazwać tematem, przy tym sposobie krystalizowania treści"). Ważne jest zaś zupełnie co innego. Po pierwsze to, że ich źródłem są drobne, intensywne, racjonalnie nie do uchwycenia doświadczenia zmysłowo-afektywne („pewien stan dynamiczny, 
zupełnie ineffabilis"); są one autentyczną prawdą subiektywnego doświadczenia, co stanowi dostateczną, realną legitymizację aktu twórczego. Po drugie to, że mają one charakter emergentny (pojawiają się „bez żadnej ingerencji woli”), nie dają się zaplanować. Po trzecie, ich cechą specyficzną jest nastrój, aura zestrojonych afektów („całkiem określony klimat”), który tropicznie przyciąga, selekcjonuje i obramowuje aktorów przedstawieniowej sceny, postaci i zdarzenia Schulzowskich mikrofabuł („wyznacza ściśle gatunek treści osadzającej i nawarstwiającej się na nim"). Ta fabularna, przedstawieniowa warstwa opowiadań jest ważna jako forma ekstrawaganckiego (dziwacznego) ucieleśniania i aktywowania afektywnego potencjału zestrojonego w „określony klimat", ton czy nastrój. To ten ostatni naprawdę się liczy; a im bardziej jest semantycznie nieokreślony (tematycznie „nikły”, ,niewyrażalny” w języku i pojęciach), tym silniejszą stanowi pobudkę do „reprezentowania wszystkiego", tym bardziej jest niewyczerpaną pożywką do „produkcji” znaczenia (dookreślania sensu opowiadań) przez czytelnika.

W moim przekonaniu te właśnie zasady kształtują sieci organizacji semantycznej Schulzowskich opowiadań. Z tego wynika, że Schulzowski model procesu twórczego jest tu zarazem modelem budowy tekstu. Teksty Schulza bowiem, inaczej, niż „dzieła ludzkie, [które - R.N.] mają tę właściwość, że, ukończone, zamykają się w sobie, odcinają od natury, stabilizują się na własnej zasadzie", przypominają raczej dzieło Błękitnookiego z Republiki Marzeń, które "nie wystąpiło z wielkich związków kosmicznych, tkwi w nich, do połowy uczłowieczone, jak centaur, wprzęgnięte w wielkie periody natury, nie gotowe jeszcze i rosnące" (P 408). Inaczej mówiąc, tekst nie jest skończoną autonomiczną strukturą znaczeniową, która zaciera i unieważnia ślady procesu swego powstawania, ale stanowi narracyjną artykulację i retoryczne opracowanie właśnie owych faz twórczego aktu (przyznaje to sam pisarz, przywołując postrzeżenia tapety z ptakami czy albumu ze znaczkami jako źródłowych tematycznych „stanów dynamicznych", które są przecież również scintillae narrationis, narracyjnymi zalążkami owych opowiadań).

Stąd o jego opowiadaniach można by nawet powiedzieć, że nie posiadają znaczenia, jeśli przez „posiadanie” rozumieć zdeponowaną i zaszyfrowaną w dziele uprzednią myśl, przesłanie czy fabularną anegdotę, którą interpretacyjna praca egzegetyczna wydobywa, wyjaśnia, uspójnia i pojęciowo precyzuje.W miejsce interpretacji egzegetycznej, pracującej wertykalnie (góra - dół, głębia - powierzchnia) działa tu „postbiblijna”, horyzontalna lektura figuralna (przedtem - potem, tekst - kontekst), w której znaczenie nie jest uprzednią daną, lecz potencjalną cechą relacyjną zawsze antycypowaną, dookreślaną 
dopiero ex post, bowiem konkretną postać nadaje jej dopiero przyszłe wydarzenie - które wszakże może nigdy nie nadejść... W tej perspektywie rozpatrywałbym właśnie również mesjańskie wątki tej twórczości, łącznie $\mathrm{z}$ „nieznanym arcydziełem” Schulza: Mesjaszem. Jakoż sądzę, że niezależnie od możliwości wyśledzenia tych wątków mesjańskich (co czyniono ostatnio parokrotnie z powodzeniem), jak też od faktu bądź hipotezy zagubienia/zniszczenia gotowego, skończonego dzieła, u Schulza w całej twórczości mamy do czynienia z „mesjanizmem bez Mesjasza” czy „mesjanicznością bez mesjanizmu”, o którym/której pisze Derrida; z „pustynnym mesjanizmem (bez określonej treści i bez dającego się zidentyfikować Mesjasza)"16.

Prefiguracyjne narracje Schulza są, mówiąc staroświecko, strukturalnie otwarte. Albo inaczej: otwierają się na to, co nadchodzi, co jednak nie może pomieścić się w horyzoncie oczekiwańn ${ }^{17}$; podprowadzają relacje o doświadczanych wypadkach na próg, za którym czai się coś absolutnie innego, co jednak, jak mówił Schulz, jest „za wielkie, ażeby się zmieścić w zdarzeniu” (P 174); nie może się wyrazić. Ta presja oczekiwania na to, co nieuwarunkowane, nieprzewidywalne, inne - na sens (ostateczny) tego, co przeczytane - udziela się czytelnikowi, który próbuje zasypać tę przepaść własnymi przewidywaniami, hipotezami, domknąć strukturę czy kontekst i „przyszpilić” czy „odkryć" znaczenie... Dotychczasowa historia odczytań dzieła Schulza pozwala sądzić, że jego energia afektywno-semiotyczno-semantyczna bynajmniej nie została wyczerpana, raczej przeciwnie: dalej skutecznie podsyca niezaspokojone pragnienie sensu czytelników.

\section{6.}

Zaproponowałem w tym szkicu bardzo pobieżną wędrówkę po tropach Schulza przez pryzmat kategorii „ekstrawagancji”, rozumianej jako retoryczna cecha stylistyczna; cecha „nastrojowego" zestrojenia afektów jego narracji doświadczeniowej; cecha postaw, wyglądów, zachowań postaci przedstawianego świata; cecha „dyfuzjonistycznego” kontekstu jego antropologiczno-kulturowego projektu; cecha metaforycznego modelu procesu twórczego; cecha „prefiguracyjnej” organizacji semantycznej opowiadań oraz cecha „mesjanicznego" wyzwania, którą aktywują one u czytelników.

16 J. Derrida Widma Marksa. Stan długu, praca żałoby i nowa Międzynarodówka, przeł. T. Załuski, PWN, Warszawa 2016, s. 57.

17

Tamże, s. 115. 
Bruno Schulz, ten niezwykły wędrowiec - ekstra wagant - po marginesach nowoczesnego życia i twórczości, wciąga nas w ekstrawaganckie eksperymenty swej sztuki, których celem jest próba „wywędrowania poza”; poza spetryfikowaną, inercyjną postać rzeczywistości, poddaną działaniowej rutynie, bezwładowi zafiksowanej formy, zamknięciu w statycznych pojęciach i języku. Nie po to, by otworzyć nam dostęp do pozaludzkiej rzeczywistości (to mityczna możliwość i utopijne marzenie), ale raczej po to, by uchwycić i przekazać ślad istnienia tego, co jest po tamtej stronie; po stronie dynamicznie zmiennej podszewki, kreatywnych przemian, na pozór niezmiennych rzeczy.

Do tego sprowadziłbym niezwykłą twórczość Brunona Schulza - której idiomatyczną formułę streszczać ma tytułowe określenie sztuki jako kulturowej ekstrawagancji - i jej prawdziwie mesjańskie zadanie: pisać tak, by poczuć - i dać odczuć - „posmak tej rzeczy bez nazwy na końcu języka”.

\section{Abstract}

\section{Ryszard Nycz}

JAGIELLONIAN UNIVERSITY (CRACOW), THE INSTITUTE OF LITERARY RESEARCH OFTHE POLISH ACADEMY OF SCIENCES (WARSAW)

Bruno Schulz: Art as Cultural Extravagance

Nycz explores how the work of Bruno Schulz can be read through the concept of 'extravagance.'This concept, which is key to the poetics of Schulz's prose, has a variety of connotations: bizarreness, weirdness, exaggeration, as well as erring, going beyond, going astray. In this article, extravagance is understood as a rhetorical and stylistic device; it is defined with reference to the 'atmospheric' harmonization of the affects of Schulz's experiential narrative; it is seen as a trait of the positions, appearances and behaviours of the characters in the fictional universe; it is understood as a consequence of the 'diffusing' context of his anthropological and cultural project; it is seen in relation to the metaphorical model of the creative process; it is seen in terms of the'prefigurative' semantic organization of the short stories, and finally as a characteristic of the'messianic' challenge that those short stories activate in the reader.

\section{Keywords}

Schulz, extravagance, bizarreness, erring, affects, experience 